\title{
PUBLIC NAD PRIVATE SHAPING OF SOVIET MINING CITY: CONTESTED HISTORY?
}

\author{
Anu Printsmann ${ }^{1}$
}

Received 30 October 2010; Accepted 15 November 2010

\begin{abstract}
The paper tells the story of the shaping of a Soviet oil-shale mining city - KohtlaJärve, Estonia - by contrasting the public sphere represented by photo-albums with private ones represented by life-stories. The reason for Kohtla-Järve's existence is oil-shale and its usage as political tool has caused the city's rise and decline in the socio-economic turmoil of the $20^{\text {th }}$ century. Yet, as contradictory as we would like to think results of visual representation analysis and a biographical approach concerning Soviet and contemporary worlds are, they both still broadly follow political and socio-economic circumstances. Imagery and life-stories are not poles apart, they just focus on different things; representations are somewhat rooted in real life and biographies are partly lived in public space.
\end{abstract}

Key words: representation, biography, life-story, landscape change, social space, industry, oilshale, Estonia

Teesid: NÕUKOGUDE KAEVANDUSLINNA KUJUNEMINE: AVALIKU JA ERASFÄÄRI AJALUGUDE VASTANDLIKKUS? Artikkel vaatleb ühe nõukogude kaevanduslinna kujunemist Kohtla-Järve näitel kasutades avaliku sfääri kirjeldamiseks fotoalbumeid ning erasfääri tarbeks elulugusid. Kohtla-Järve on tekkinud põlevkivi tõttu, see on põhjustanud nii linna hiilgeajad kui ka mõõnaperioodid sõltudes 20. sajandi poliitilistest keerdkäikudest. Kuigi kui vastandlikena ka visuaalsed representatsioonid ja biograafiad ka ei tunduks, järgivad nad siiski samu poliitilisi ajajärke, keskendudes küll elu erinevatele tahkudele.

Võtmesõnad: representatsioon, biograafia, elulugu, maastikumuutus, sotsiaalne ruum, tööstus, põlevkivi, Eesti

\section{Introduction}

Mining, although producing life's necessities for humankind, is usually detrimental to the natural environment and also to the social one in the long run. The process of setting up a new mine is time consuming in democratic societies because of deliberation. Alternative locations, other resources, management, opening and closing costs and practices, influences on people's health and livelihood etc. have to be considered in a state where allowed environmental impacts are ever-tightening. Creating a mine in totalitarian regime seems simpler as the only thing necessary was an order from "above"; supplying natural resources for demand elsewhere and not much considering (or having the right to) future consequences. This is the first

\footnotetext{
1 Anu Printsmann, Researcher, Centre for Landscape and Culture, Estonian Institute of Humanities, Tallinn University, Uus-Sadama 5, 10120 Tallinn, Estonia; e-mail: anu.printsmann@tlu.ee
} 
approximation but history is always contested, whether implicitly or explicitly. What is a more detailed account for a Soviet mining city's life course?

The aim of this paper is to show this contestedness by the tale of the Soviet oil-shale mining city Kohtla-Järve, Estonia from two vantage points: public and private. Despite discrepancies in discourses concerning public and private realm remain inextricable to every social system they are especially conspicuous in totalitarian regimes. Two complementary methods of visual representation and biographical approach have been used to explain the shaping of the city by imagery and everyday spheres.

For making clear the relation between researcher and subject as demanded by Apo (2003): the author comes from Kohtla-Järve, her parents moved there in 1958 and 1968, and she lived there until 18 years of age, thus she has an insider's perspective. Also Apo (2003) claims that nowadays the opposition between etic and emic positions has dissolved and both viewpoints have to be considered, still acknowledging their difference. Etic position is necessary to understand thwider socio-historical context, which helps to interpret the emic position in lifestories.

\section{Kohtla-Järve as the quintessence of the soviet industrial landscape}

The reason for Kohtla-Järve's existence is oil-shale. Whereas oil-shale has been mined, chemically processed and used for energy it has also constituted as a political tool causing glorious and less glorious days to the region known as the "Land of Oil-shale".

Although the hearsays of peasants' saunas built from stone catching fire and scientific investigations of $19^{\text {th }}$ century it was the fuel crisis of the First World War that started the industrial mining of oil-shale in 1916. Small-scale foreign capital based industrial enterprises helped to spread innovative ideas like using electricity and principles of garden cities in the otherwise rather rural, sparsely populated and agriculturally oriented area.

Following the Second World War the Soviet Union demand for oil-shale sky-rocketed resulting in foundation of a new mining city called Kohtla-Järve in 1946. The name of the city was borrowed from the neighbouring villages of Kohtla and Järve partly on which lands the city was established. The farmsteads had to make space for city dwellings to accommodate the evergrowing number of workers (figure 1 and 2). The need for working hands was solved by immigrant workers: $80 \%$ of Kohtla-Järve's population is currently Russian-speaking (KohtlaJärve's official web page); the same rate goes also for Ida-Viru county ${ }^{2}$.

Although stories of peasants' saunas built from stone catching fire and scientific investigations of the $19^{\text {th }}$ century showed an early interest in the regions potential for energy exploitation, it was the fuel crisis of the First World War that started the industrial mining of oil-shale in 1916. Small-scale foreign capital based industrial enterprises helped to spread innovative ideas like using electricity, and the principles of garden cities in the otherwise rather rural, sparsely populated and agriculturally oriented area.

Following the Second World War the demand for natural resources sky-rocketed resulting in hundreds of new mining towns all over former Soviet Union. Kohtla-Järve was founded in 1946. The name of the city was borrowed from the neighbouring villages of Kohtla and Järve partly on whose lands the city was established. The farmsteads had to make space for city dwellings to accommodate the ever-growing number of workers (figure 1 and 2). The need for working hands was solved by immigrant workers: $80 \%$ of Kohtla-Järve's population is currently Russianspeaking (Kohtla-Järve's official web page); the same rate goes also for Ida-Viru county ${ }^{3}$ (Statistics Estonia 2010).

Oil-shale mining in Kohtla-Järve was directly subjected to the Ministry of Coal Industry in Moscow. As a result the city became the regional centre despite the fact that there were older and bigger cities nearby (figure 2). Kohtla-Järve was the capital of Oil-shale Land.

\footnotetext{
${ }^{2}$ Statistics Estonia - www.stat.ee/en - 10.10.2010

${ }^{3}$ Statistic Estonia (www.stat.ee/en - 10.10.2010)
} 


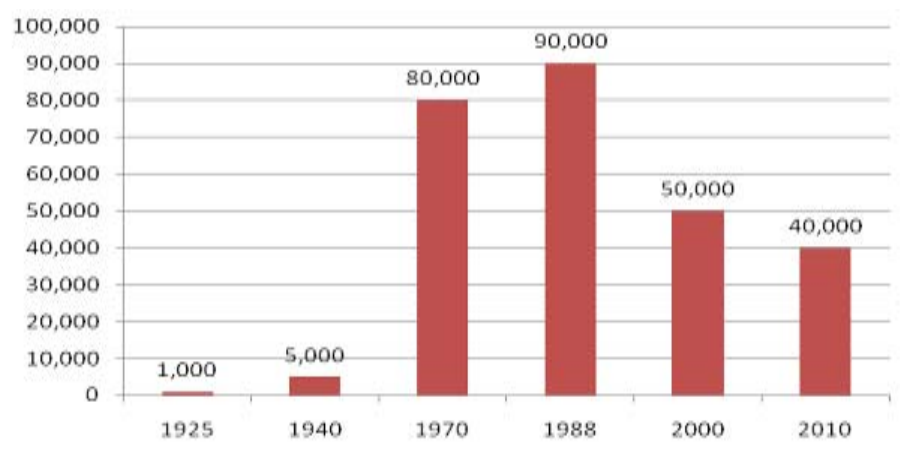

Fig 1. The approximate number of inhabitants in Kohtla-Järve (source: ENE 1972: 50-51, ENE 1989: 625, Statistics Estonia 2010) involving all urban districts of the city in a given year (see figure 2).

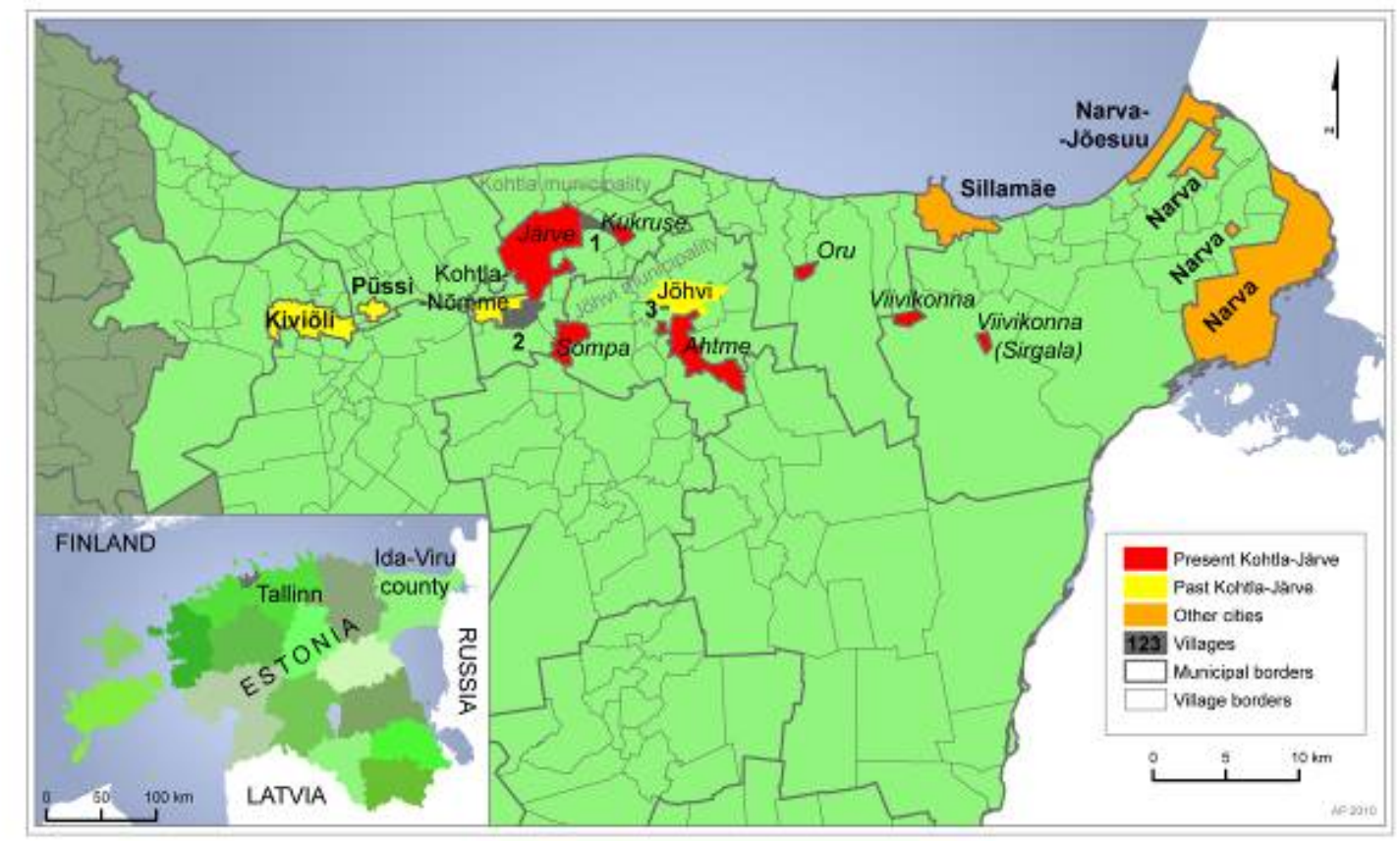

Fig 2. The Land of Oil-shale reaches approximately the extent of today's Ida-Viru county (area $3400 \mathrm{~km}^{2}, 170,000$ inhabitants, over $80 \%$ of them live in cities) that during the Soviet period was the region of Kohtla-Järve. Kohtla-Järve was then and it is now a conglomerate city having its urban districts spread over $30 \mathrm{~km}$. Now some of them have regained independence. One of the former urban districts - Jõhvi (first mentioned 1241, town rights 1917 and city rights 1938, part of Kohtla-Järve 1960-1991, Kohtla-Järve's administrative centre 1960-1977; 12,800 inhabitants) - is now the capital of Ida-Viru county, although it is a city without municipal status. Neither Kohtla-Järve nor Jõhvi are the biggest cities in the area; it is Estonia's easternmost city Narva (65,800 inhabitants) where "brown gold" is burned in power plants (whose ash creates acid rains) giving electricity to all Estonia. The western limit is in Kiviõli (direct translation: stone oil; founded 1922, city rights 1946, part of Kohtla-Järve 1957-1991; 6600 inhabitants) that dealt with the chemical industry, and now features a debate with two businessmen vying for quarrying rights, shale oil and energy. Püssi (first mentioned 1472, town rights 1954, part of Kohtla-Järve 1960-1993, city rights 1993; 1800 inhabitants) is known for producing furniture components and being the first municipality that was saved from bankruptcy by the Estonian national government; it has a commitment to join with another municipality but they have not found one yet; several of the citizens have to face the winter without heating. Settlement around Kohtla mine (1937-2001) was an English-type garden town that was named as Kohtla-Nõmme after the Second World War, gained town rights 1945, was part of Kohtla-Järve 1959-1993 and forms now a town and a municipality with 1000 inhabitants. Sillamäe was first mentioned in 1502; it was a resort area together with Narva-Jõesuu by the end of $19^{\text {th }}$ century for elite from St. Petersburg, Russia; because of Uranium mining and processing it was a closed city 19471991, city rights from 1957.

Villages: 1 - Järve village, 2 - Kohtla village, 3 - Jõhvi village (source: Estonian Land Board 2010, Statistics Estonia 2010).

Kohtla-Järve lost its special status with the collapse of the Soviet Union. The capital of Oil-shale Land faces all the troubles known in so-called rust-belt-zones as the regime that has created it and supported its over-production for local needs has ceased. The amounts that Estonia needs nationally are times smaller and oil-shale production fluctuates depending on the Russian market's cut-offs and re-openings (figure 3 ). 


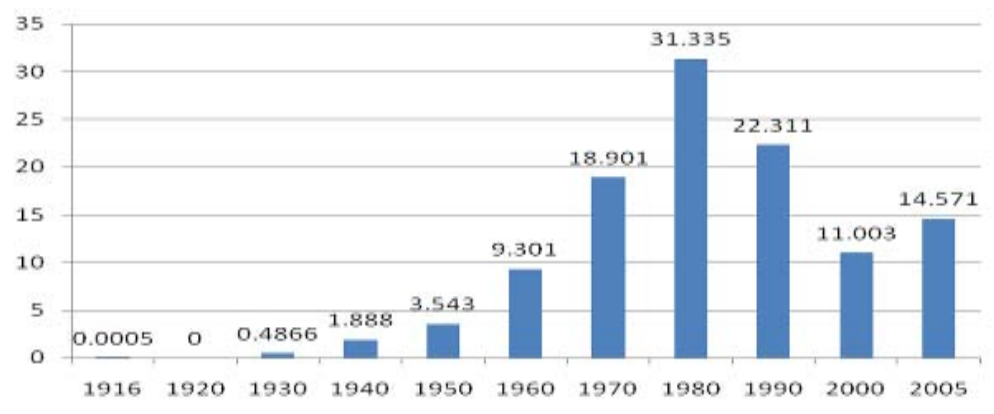

Fig 3. Production volumes of oil-shale in millions of tons (source: Varb and Tambet 2008: 8-9).

Alongside economic problems, environmental concerns could be voiced which was not possible before. Closing an underground mine whether due to shortage of oil-shale or selling opportunities, is expensive to do if done properly. Quarries need to be recultivated; allegedly Kohtla-Järve was a forerunner in the world in the 1960s-1970s. Mining's side-product limestone - is deposited into heaps but if it contains too much oil-shale it can ignite. Energy production by burning oil-shale causes air and ground-water pollution and the so-called 'ashhills wasteland' if not built according to standards. Chemical processing by heating without oxygen pollutes air and produces semi-coke that is stored in heaps where phenols can leak into the soil and water. Environmental awareness has definitely been rising, meaning that the consequences of past actions are scrutinized with ecology in mind. Of course, it is always a question of prioritising where to put one's finances, but arguably safeguarding human resources was not an issue during the Soviet period. Contemporary requirements are higher and environmental monitoring is in effect.

Economic problems are unavoidably translated into social troubles and ethnic tensions: unemployment, difficulty in acquiring new labour skills, an aging population demographic (30\% of people are retired), language issues and citizenship, low income, high maintenance costs for apartments, abandonment and demolition of houses, crime, drugs, AIDS etc.

Excess industrialisation, immigration and urbanisation have constituted the nexus of economic, ecological and social problems, degrading Kohtla-Järve's public image. Kohtla-Järve was like any other Soviet mining city with an up-to-date clear city plan layout, multi-storeyed new housing, tap-water, effective collective infrastructures: hospitals, parks, kindergartens and schools. But as a rather mono-functional settlement it now represents (perhaps unfairly) the changes that took place in Estonia after the Second World War (see Palang et al. 2006) being the quintessence of all bad that the Soviet period represents.

Yet, the heavy industrial constellation has shaped the land, featuring phenomena that cannot be found elsewhere (figure 4) hopefully inducing tourism and local identity-building. Due to good access of fuel, energy and natural gas from Russia industrial clusters have formed in KohtlaJärve, producing benzene, benzoic acid, sodium and potassium benzoate, plasticizers, mineral fertilisers, technical grades of liquid and aqua ammonia, prilled urea etc., also used in local enterprises for raw materials in producing impregnation oil, varnishes, resins, road asphalt, sulphur, tanning materials and detergents. Thus, the first thing one notices when reaching the Land of Oil-shale is smell; secondly the eye meets so-called ash-hills, (common name for all three types of residual heaps; around 40 on an $80 \mathrm{~km}$ stretch of land) on an otherwise flat landscape that are over $100 \mathrm{~m}$ in relative height. Since the beginning of the $20^{\text {th }}$ century over $400 \mathrm{~km}^{2}$ (close to $1 \%$ of Estonian territory) have been mined, whether underground or in quarries by 2007 (pers. comm.) producing over 100 million tons of usable oil-shale by 2006 (Varb and Tambet 2008), not to mention waste materials like limestone. The careful eye can also detect signs of yesterday's progress now abandoned: non-efficient structures have been left behind, industrial chimneys from the 1920s stand alone, overgrown apple-trees that once surrounded now non-existent farmsteads and almost deserted workmen villages. 


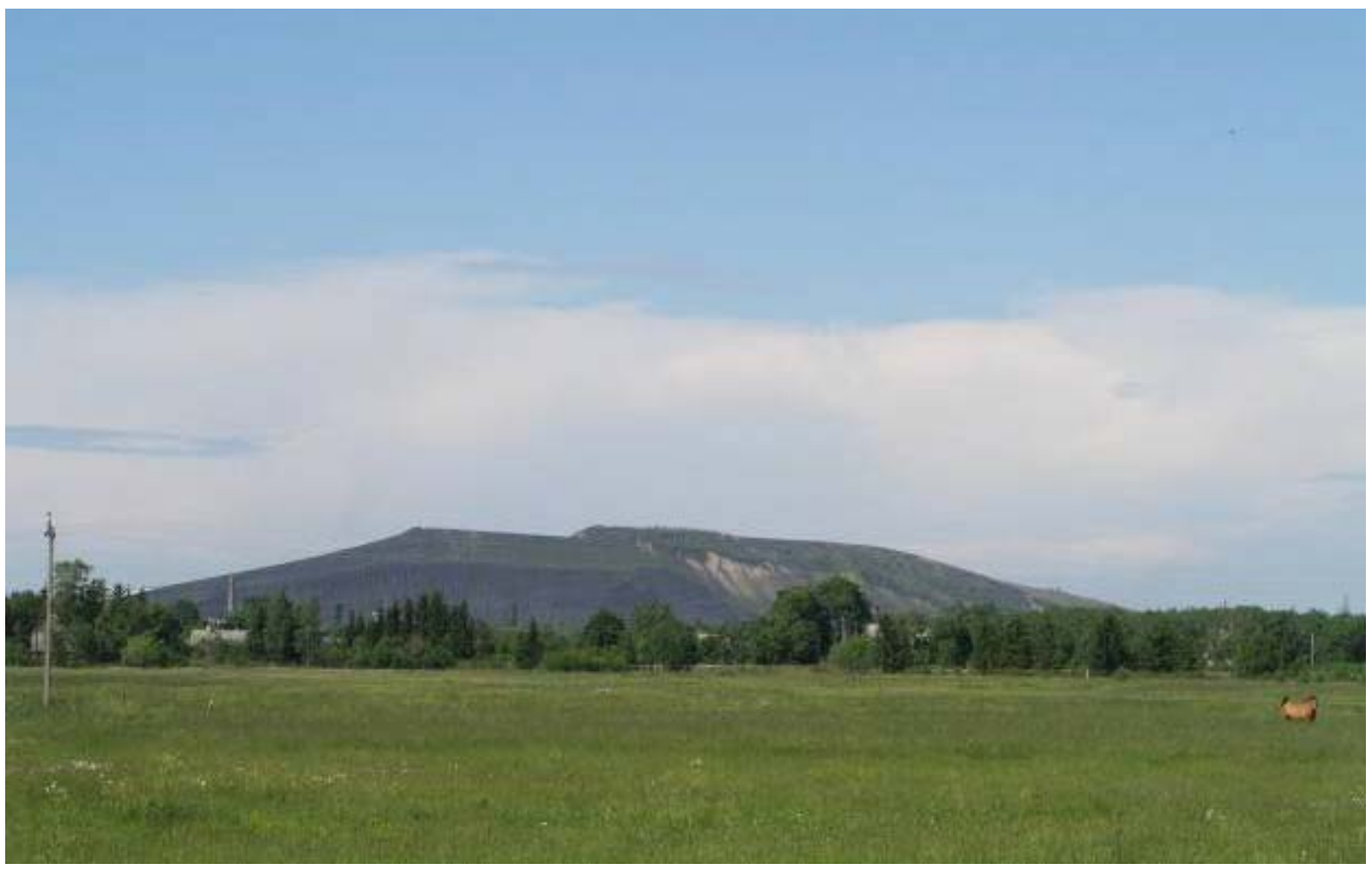

Fig 4. View of so-called ash-hills (here actually semi-coke hills) of Kohtla-Järve as the backdrop of agricultural landscapes (photo: A. Printsmann, 2.07.2007).

\section{Methods and materials}

In the current study two complementary methods are used to show the story of shaping a Soviet mining city by public and private spheres as they both direct our understanding of "reality". Visual representational analysis looks at how landscapes were imagined, set as an example, what portions of the land or details represented the ideology best, how they were captured (Howard 1991, Krim 1973, Linnap 2006, Rose 2000, Scott 2004, Sontag 2002, Thrift 2000). The Biographical approach (Bryman 2002, Humphrey et al. 2003, Passerini 1992, Roberts 2002) delves into the interpretation of everyday lives (de Certeau 1988) and the ordinary landscapes (Jackson 1984, Meinig 1979) of insiders (Relph 1986): was landscape change detected, was it perceived as gradual or abrupt, how well did locals adapted to it, how did these attitudes form, what was regarded as noteworthy and does it coincide with public imagery. Despite the usage of different material, and outcomes reach different hierarchical levels, both methods feature some common traits.

Both methods of visual representational analysis and biographical approach are of a qualitative nature, being rather elitist and highly selective as material is not bulky. Landscape imagery in photo-albums have gone through multiple selection filters: selection of photographer, photographs (with all its aspects: angle, colour, exposure etc.), typical or remarkable objects that convey ideas best etc. Despite the top-down selection process and thorough Soviet censorship, a style called "socialist content, nationalistic form" was still possible (see Linnap 2003, 2006, Sooväli 2004, Sooväli et al. 2004). Life-stories of common people were not dealt with during the Soviet period, only biographies of famous people (preferably already dead) were published with remarkable gaps or silences in not approved areas, e.g. the Estonian 20-year independence period was omitted or covered with couple of sentences referred to as "bourgeoisie" (Hinrikus and Kõresaar 2004, compare to "A right for biography" by Lotman 1990).

The selected methods feature compressed forms of time and space, and as such are not highly representational and do not allow any deep conclusions but despite their constraints they are both tackling the public or private aspects of a Soviet mining city while simultaneously problematising the concept of "real". Visual representational analysis and the biographic approach reflect a subjective ((un)consciously beautified) reality. Detailed accounts of specific particulars are unimaginable; generalisations and embellishments are in place, giving even 
more information to the researcher. Though not always worth mentioning, strategies of how to cope with everyday practicalities are interesting as well. Memory "tricks" in life-stories, such as coalesced uniform periods in one sentence and lengthy descriptions of a "night that changed the world" are unavoidable. Therefore the notion of a life-story is used instead of life history. Both methods use as their material pre-recorded pictures and texts imbued with period context (totalitarian or democratic regime) as being a creation of their time, as well as the interpreters' which makes the study even more intriguing.

Another time-bounded quality binds these two methods: their application in Estonian context (Peil 2006, Peil et al. 2004) that has been fairly recent, since re-independence. Ways to dissect the overtly propagandist pictorial language were not possible during the totalitarian regime (on representations see Berg 2002, Jauhiainen and Kulu 2000, Lehari 2006, Linnap 2003, 2006, Peil and Sooväli 2005, Sarapik 2002, Sooväli et al. 2003a, b, Sooväli 2004, Sooväli et al. 2004). The "Biographical turn" was seen as one of the possibilities to "give back history to the nation" and "erasing history's white patches" (on life-stories see Aarelaid-Tart 2006, Hinrikus 2000, 2003, Hinrikus and Kõresaar 2004, Hinrikus et al. 2006, Kirss et al. 2004, Kõresaar 2004, Paju 2007 ) but not yet much applied in geography and landscape studies. Calls for sending in lifestories emerged in February 1988, and were published in newspapers in 1989. Still, in 1997 troubling questions concerning the writer's safety if the "Russians" ever come back surfaced. In 2003 the first calls in Russian appeared (Hinrikus and Kõresaar 2004).

A life-story may be regarded as a representation: representation of a self, retrospective life, origin, generation or nation, of "how things were back then" having the same flaws as any other representation: partiality showing off good sides or presenting selective truths consciously or not etc. As Harvey (1997: 96) has put it:

All societies, classes, and social groups possess a distinctive "geographical lore", a working knowledge of their territory, of the spatial configuration of use values relevant to them, and of how they may intervene to shape the use values to their own purposes. This "lore", acquired through experience, is codified and socially transmitted as part of a conceptual apparatus with which individuals and groups cope with the world. It may take the form of a loosely-defined spatial and environmental imagery...

Similar to a life-story account, a series of visual representations make up a narration having a beginning, middle and end, twists, highlights and punch-lines - a moral, and a message to convey (Cronon 1999) from a certain (higher hierarchical level) vantage point depending on story-telling time.

\subsection{Visual representational analysis of landscapes}

Representation denotes a variety of connotations (see Merriam-Webster Online Dictionary and Antrop 2004, Cosgrove 1999, 2000, Daniels and Cosgrove 1988, Duncan 2000a, b, Hall 1997, Haraway 1997, Knapp and Ashmore 1999, Krim 1973, Lefebvre 1991, Lowenthal 1985, Mitchell 1994, Olwig 2004, Schama 1996) but in the following three meanings are under scrutiny:

1. one that represents as an artistic likeness or image,

2. a usually formal statement or account made to influence opinion, action or effect a change,

3. the substitution of an individual or class in place of a person so as to have the rights and obligations of the person(s) represented (especially in a legislative body).

The focus will rest on photo-album imagery - the selection of landscape representations both on objects and in terms of depiction in time and place sequences. "The geographic problematic stems from the fact that we cannot accept reality as it is and so we create places to transform reality into what we think it ought to be, and then transform this new reality, and so on" (Sack 2001: 117).

The studied material comprises 20 picture books covering the period from 1948-1990 and around 10 from the re-independence period as a publishing boom of tourism related picturesque books continues. Estonian photo-albums published outside Estonia are not included (see outsider's view in Vesilind 1980). The primary aim of the coffee-table books is to introduce 
the remarkable, peculiar as well as ordinary places of the country; still some books were dedicated only to the region of Kohtla-Järve. Both the representations of the cityscape and oilshale industry are studied.

\subsection{Biographical approach}

"The intention in the study of lives is to gain an understanding of individuals' life experiences within their socio-historical context" (Roberts 2002: 13) and their turnovers (see Palang et al. 2006). As this work's interest lies in the private sphere of a city in everyday life and how landscapes were perceived and formed (affected by (un)conscious prevailing ideology via visual representations) by ordinary people, the focus is on analysis of narratives not narrative analysis. Obviously, not too much effort is paid to literary descriptions of landscapes in life-stories. Thus, in vivo codes from a selective coding of core categories from grounded theory method (Glaser and Strauss 1967, Strauss and Corbin 1990) are used putting a finger on significant phenomena. "In vivo codes "have two characteristics: analytic usefulness and imagery"' (Strauss 1994: 33).

Thematic life-story narratives and some interviews in this paper come from the Estonian Cultural History Archives from the years 1989-2001, also materials (life-stories, interviews and letters) from the archives for the Chair of Estonian and Comparative Folklore, University of Tartu (the collection contained 19 story-tellers or writers as of the beginning of 2005) (Jaago et al. 2007). Additional thematic life-story narrations from a call in 2000 entitled "Me and My Family in ESSR and Estonian Republic" were used.

To use the methods of the early $20^{\text {th }}$ century sociologist Chicagoan approach (see Roberts 2002) when individuals were treated as social personalities then "typical lines of genesis" are retrievable for Kohtla-Järve life-stories as well. "Typical lines of genesis" for Kohtla-Järve could stem from:

1.villagers of Kohtla and Järve,

2.Estonians who moved or were directed there during Soviet times (including Estonians who survived deportation to Siberia and were not allowed to settle in their previous home region) in search of a job and lodging and who are literate (see Widgren 2004) also the previous layers of landscape,

3.immigrant workers from the rest of the USSR, a by no means homogeneous group but not enough studied to distinguish sub-groups.

One (carefully selected) life-story may be regarded as the substitution of a class/gender/age/ethnic specific view or representation. Due to Estonia's historic peculiarities collection of life-stories focuses on the Estonian ethnic view; in this paper it is represented despite the fact that Estonians form a minority in Kohtla-Järve and it definitely diverts from Russian-speaking views (De Grave et al. 2006).

\section{Findings and discussion}

In this chapter emergent themes from visual representational analysis of landscapes and biographical approach are set into a dialogue to reveal the play of public and private levels; it will demonstrate how period specific conditions (etic socio-historical context) affect biographies along with giving understanding of individuals' life experiences.

\subsection{Chronologies}

The most prominent common theme is the recording of passing time, chronology. On the representational side, the development of a technological innovation (see Krim 1973): from black-and-white albums to albums with some coloured panels to fully colour photos on quality paper, with occasional or full retouching (mainly with red) of pictures. Also the number of books shows an exponentially increasing trend - now everybody has the right for an opinion.

The quality of paper could also serve as a basis for a chronology of life-stories: good quality paper was not retrievable at the end of 1980s; writing was done in simple school exercise books not by typing machines (owning one during Soviet period was prohibited) or computers. Along 
with the national re-awakening the peak of writing life-stories remains the end of 1980 s to the beginning of the 1990s - looking back at the revolutionary developments. At first, most of the life-stories are from the so-called betrayed generation born in the 1920s and often sent to Siberia who could heal themselves by publicly speaking of things not possible before.

Previous historic periods seem coherent at first examination but even the Soviet period could be sub-divided according to Soviet Party leaders with somewhat different policies and "thaw" episodes. Going even deeper, early and late years of each leader could be distinguished and so on. It is much more difficult to say something substantial about the present as the genus tempori has not settled yet.

The 1950s-1970s were carried along by the idea of industrial appraisal in Estonia (figure 5). The icon of this was Kohtla-Järve which together with images of mining and living in the modern city, created a feeling of a real utopia (figure 7). In the post-war period it was a place where modern built-up work could be captured, avoiding the apparitional ruins in the backdrop. Rachel Carson's Silent Spring was published 1968 in Estonian. Pictures of successful re-cultivation of open-cast mines appear as early as the 1970s (Jüssi 1973, Sein 1976; figure 6). The photos of the region's natural monuments over industrial ones start to prevail in the 1980s, though usually one picture depicting a quarry with machinery is kept. In contemporary books nature monuments are in the forefront and only some views to distant ash-hills appear occasionally a trend in rapid change hopefully: local initiators give fiery talks of the beauty and heritage value of altered landscapes, trying to avoid the often used term of shock-tourism.

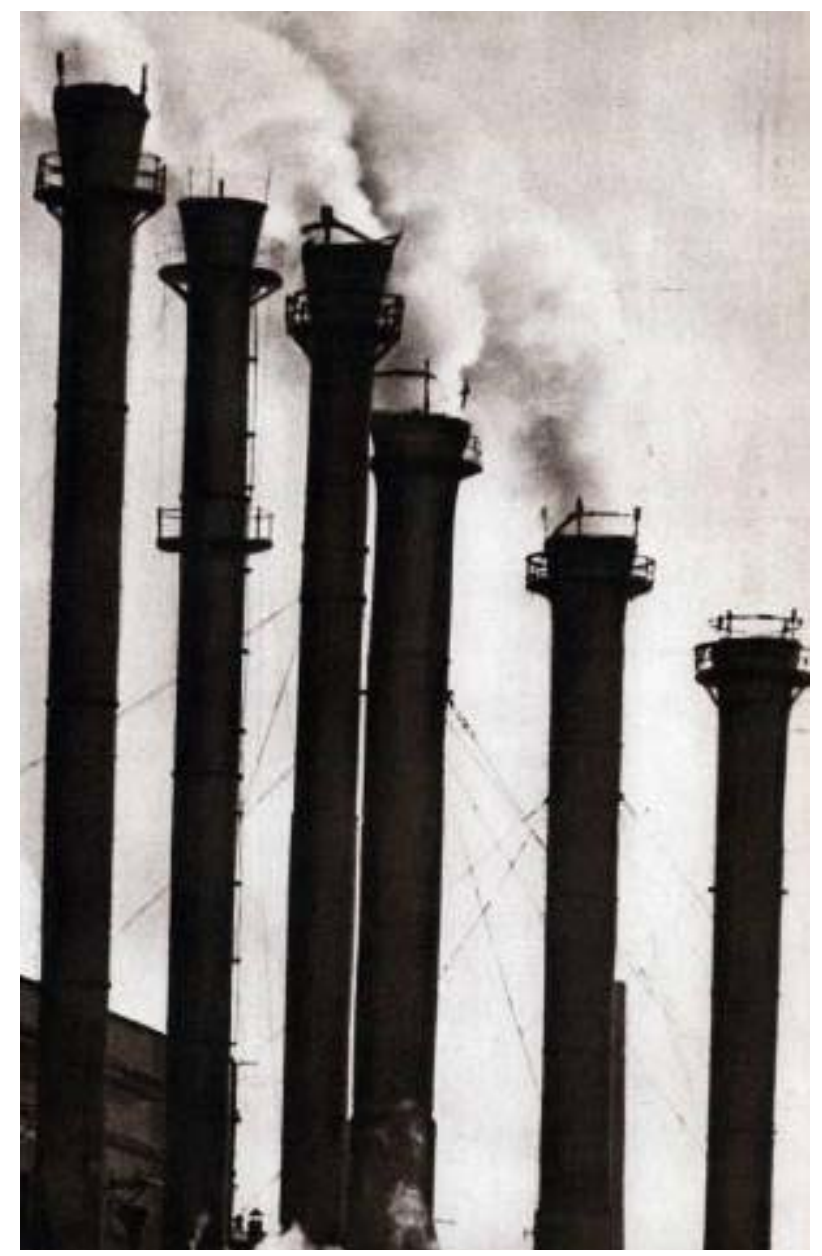

Fig 5. Almost graphic depiction of chimneys from bottom to top to perceive their majestic character, number and rhythm; ignore the smoke (source: Migdal 1968: 17).

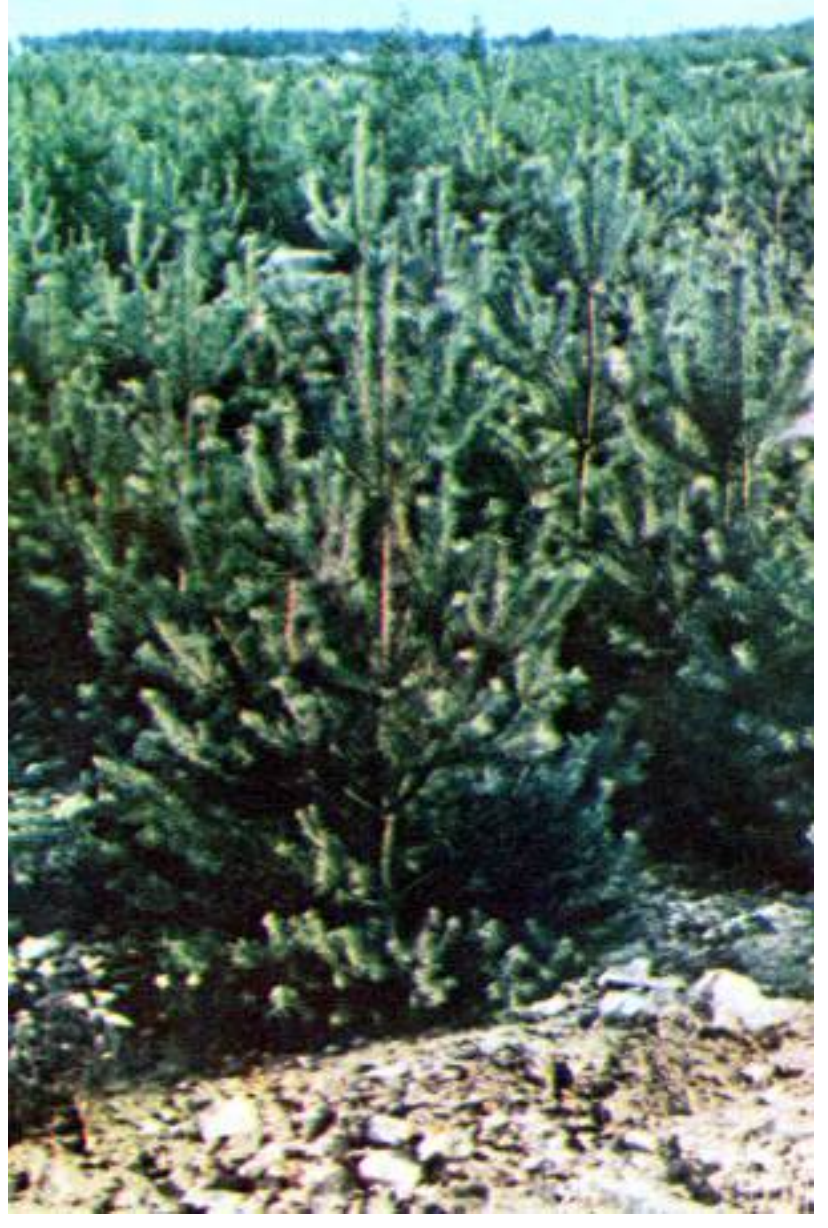

Fig 6. How old quarries are levelled and afforested (source: Jüssi 1973: 77).

Some inclinations can be even read out from the titles of the books dedicated only to the region of Kohtla-Järve: "Miners' Country" (Migdal 1968), "The Capital of Oil-shale Country: KohtlaJärve" (Sein 1976) and "Estonian Northern Coast" (Ranniku and Uusi 1993), although also 
during the Soviet period nature photo-albums were possible: "Pictures from Alutaguse" (Alutaguse being the historic name for Ida-Viru county) (Jüssi 1973).

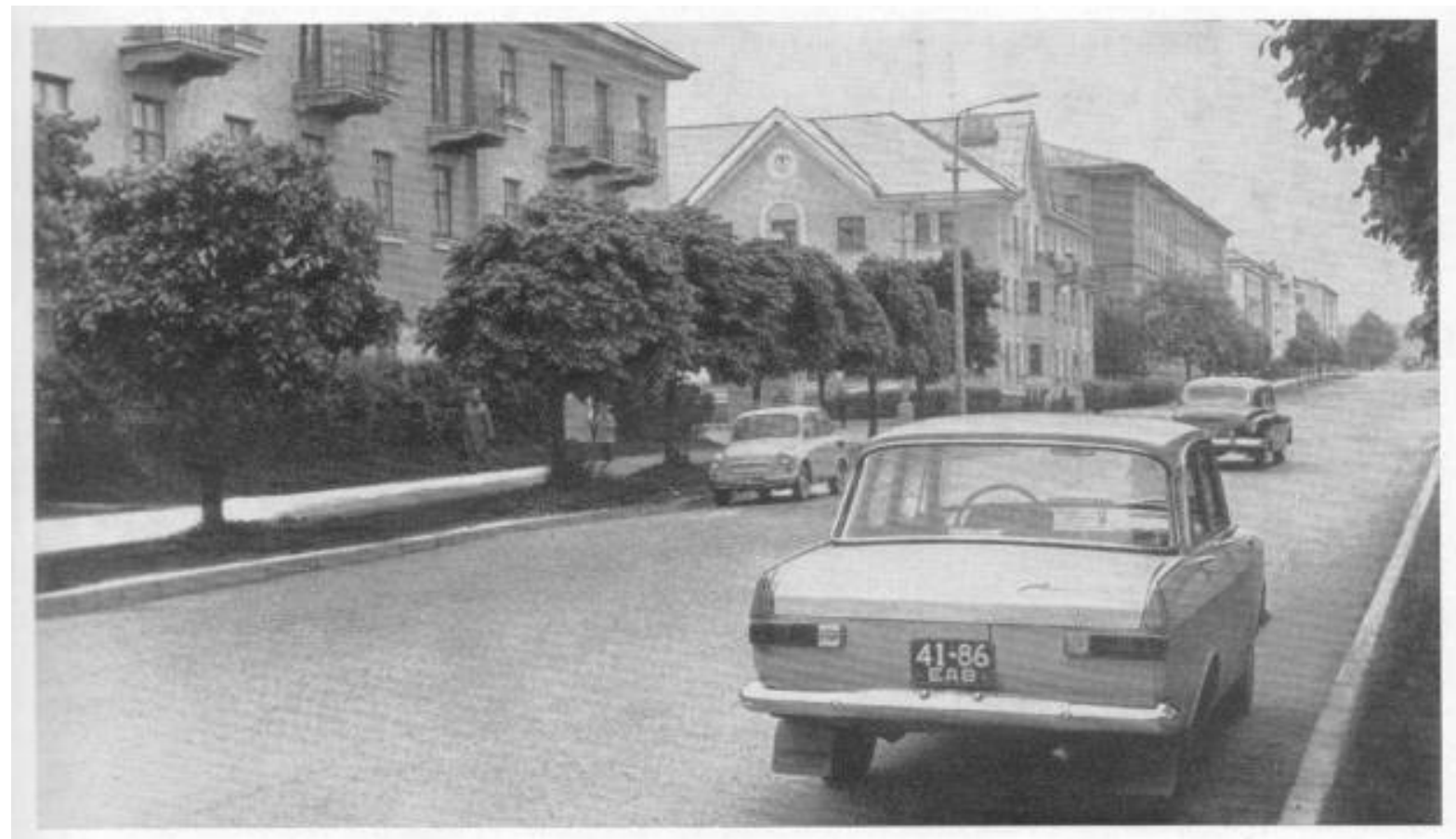

Fig 7. Nice, new, clean Soviet city with Stalinist style architecture; wide, regular, straight streets with trees. Though, Cars could be purchased only with special permissions that were not given to everybody (source: Sein 1976: 65).

In life-stories four major break-points concerning oil-shale mining activities expressed in city developments can be found, two of them more subtle ones. First, a gradual change in the local countryside when oil-shale was being extracted: pieces of one or that meadow were bought up by mining companies. Unstable underground constructions resulted in land collapses where horses fell in so far only their ears could be spotted.Secondly, the horrors of Second World War and consequently sudden re-organisation of all aspects of life: the houses of Järve villages were demolished to allow erecting so-called Finnish reparation houses by German war prisoners. Some compensation for land was given but creation of a new city went with such a hurry that collective farms were not formed in the adjacent villages. The first wave of immigrants arrived but Estonian life-stories concentrate on personal lives in hard conditions - one city space conjoined totally separated social and ethnic groups. It seems that the repeatedly mentioned fights between Estonian and Russianspeaking boys had begun already then. On the other hand, it was the time of silences ignorance was sometimes the best defence against deportation to Siberia (last one in 1949). Adjusting to changes, specifically rural conversion to an urban fabric of life, which lasted from the 1950s until the 1970s, is characterised by fitting the place and time into place metaphors, e.g. Tahmalinn (Grimetown) and Järve instead of Kohtla-Järve in letter headings (Jaago et al. 2007). Järve village was replaced by Sotslinn (in Estonian) or Sotsgorod (in Russian) meaning the socialist city, now again named Järve urban district (see figure 2). Former land use patterns were completely wiped out in places where houses were substituted by semi-coke hills.

Many story-tellers feel the third turning point to be the end of 1970s, beginning of 1980s, when the small garden city was turned into something unacceptable to Estonians (Jaago et al. 2007; figure 8):

There is no old Kohtla-Järve anymore. Most of it was destroyed by the nitrogen fertiliser factory (the houses fell into a sanitary buffer zone); some by expansion of the oil-shale plant, and part was just abandoned when a chance appeared to get an apartment in Sotslinn with central heating, tap water and a bathroom. 


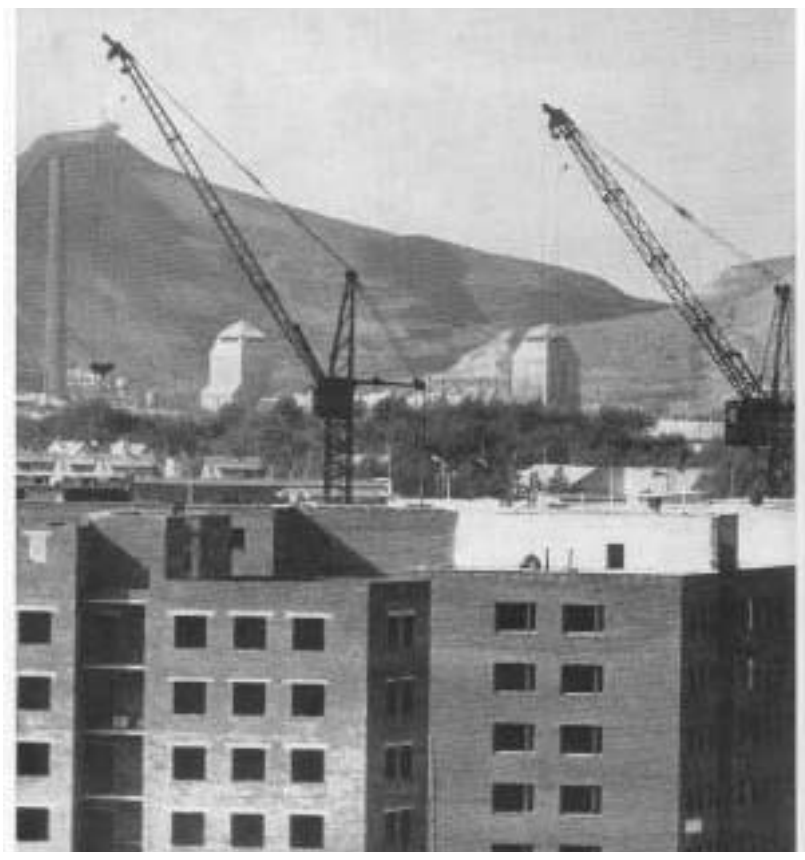

Fig 8. "The construction of the nitrogen fertiliser factory in the 1960s" (Sein 1976: 46).

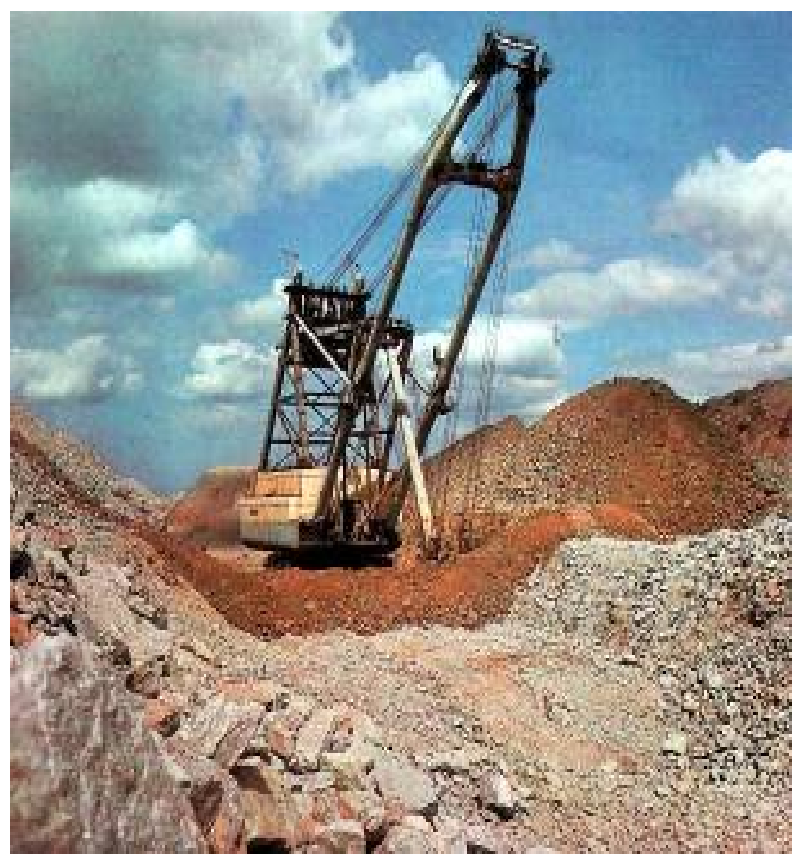

Fig 10. An example of mid-1980s photo-album covering all Estonia and featuring only two pictures from KohtlaJärve: blue sky, white clouds and massive fields of "brown gold". This is definitely not a settled place (source: Itra 1985: 11).

It was the time when former villagers of Järve who had built their new individual houses on Punane (Red) street had to once again leave their houses and move into 5- or 9-storied "highrises". Places were necessary to accommodate the new immigration wave from the east that over-exceeded the carrying capacity threshold, causing unavoidably the loss in general upkeep. A city that was perceived as nice and tidy became bigger and sloppier because of the new "rootless" people and loss of sense of private property and responsibility:

More and more often two cultures collided, or two lacks of culture, to be more exact, so that the sparks flew. One thought, this is our country now, the other, that this is our homeland.

The 1990s change in landscapes somehow does not reflect in life-stories as something traumatic; it is the beginning of long-lasting decay that has not ended now (Jaago et al. 2007; figure 9):

Now I have a home in a block that has 150 one-room-apartments. I live alone, in my warm nest, and I do love it. I protect it with two locks and at night also with a chain and an eye in the door, because somebody else has been using my new, only half-year-old TV, radio etc. for 1.5 years already. The stairs are always filled with fainting people, dog shit, junk and drunks. Some flats are occupied by "businessmen", some by normal people.

Compared to other places in Estonia, Kohtla-Järve is an unhappy and God-forsaken place. /.../ The former Sotslinn and other new districts leave a rather disconsolate and neglected impression. /... When I go out to see my sister, I stick my hand through a hole in the door left at the place where a lock once was. This is the business card of the present-day Kohtla-Järve for me and makes me feel dejected.

Hard economic times, the ecological issues, and ethnic conflicts have been rather submerged, like right after the Second World War; people are concerned for the well-being of themselves. Maybe the common concern for the city's upkeep helps to overcome the ethnic discrepancies? 


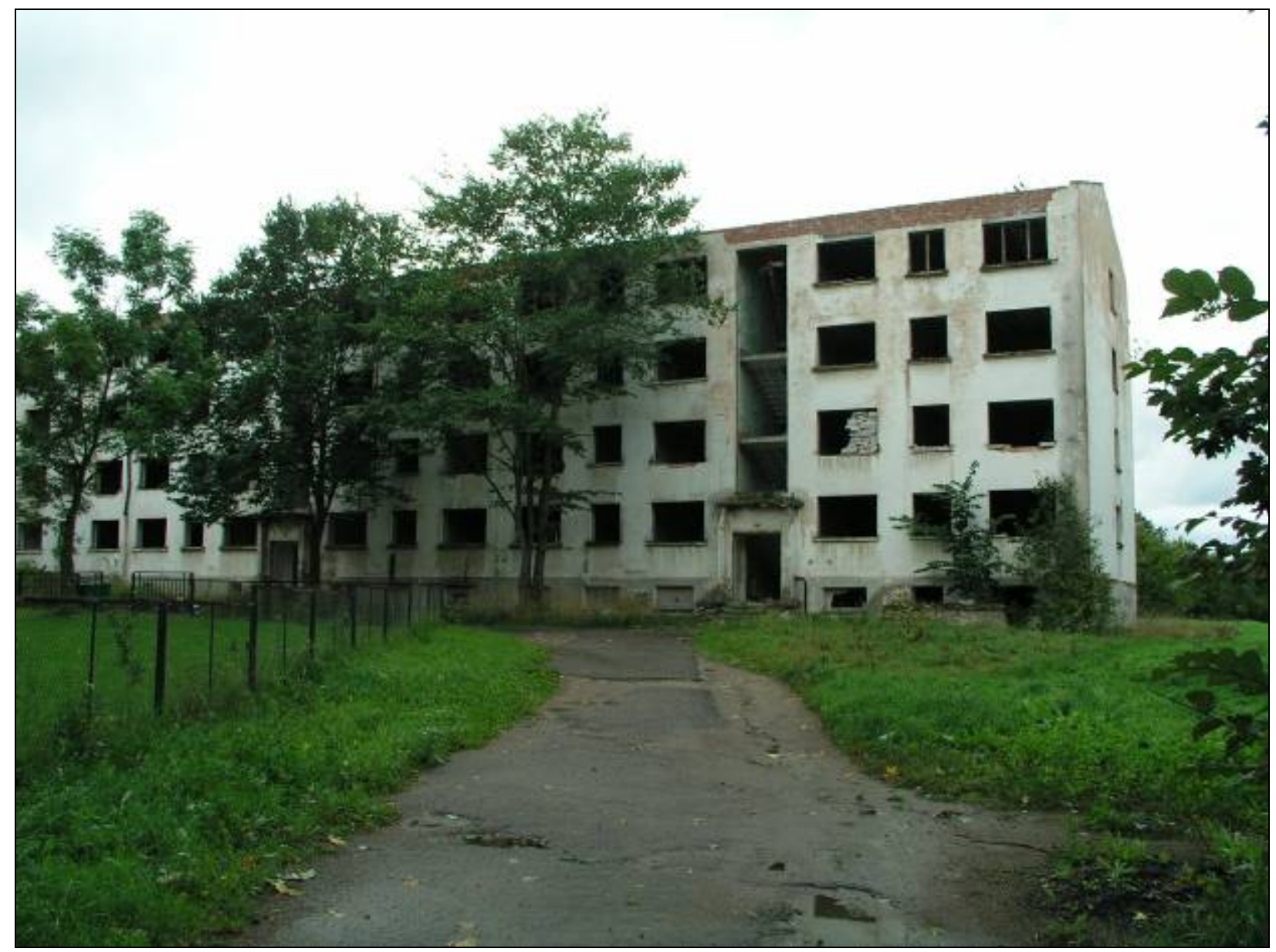

Fig 9. A neglected house (photo: A. Printsmann, 8.09.2004).

\subsection{Propaganda and progress}

Chronologies have tight connections to the idea of progress. Kohtla-Järve was the most represented region after the capital Tallinn in the photo-albums in the post-war period. Here the myth of Kohtla-Järve as the quintessence of the Soviet industrial landscape was born. The images stress the importance of overcoming nature and using nature as a resource, in the words of (in)famous Ivan Mitchurin: "We do not expect gifts from nature, we take them ourselves" (figure 10). The city is represented by photos from high vantage points, panoramas and skylines (compare Krim 1973) demonstrating contemporary planning and commodities; stilllives of staged everyday urban street activity appear later. Kohtla-Järve gained its status as a symbol of progress by offering a perfect location for photo-sessions which would effect a change in the rest of the country: from agrarian into industrial society with all its amenities and camaraderie of the people. It was an embodiment of the happy future that communism propagated. Pictures of people dealing with their hobbies and recreations are commonly situated in the back of the books, after the industrialism has been envisaged fully (figure 11).

The industrial progress is illustrated by a metaphoric night- and underground-shots with beams of light coming through the darkness resting on heavy machinery; huge pipe constructions are photographed from below and there is a great deal of drama and optimism in these photos, stressed with blue sky and white clouds. The mining factories and territories are often represented in sunset or special daylight providing a dramatic setting for displaying the power of industry (figure 12).

As many of the Soviet period photo-albums feature parallel texts besides Russian in English, German and sometimes Finnish, they were aiming at popularising the ideas beyond the Soviet border. The texts accompanying the photos vividly express the nature of ideology and emphasised industrialisation (Migdal 1968: 8):

Weary shoulders, aching muscles and cramped fingers - this used to be the succession of feelings during the "spade-era" of oil-shale mining in the bygone days. In this way 
the open-cast mine was established at Kiviõli in 1922. That cheap "technology" of mining prevailed until the great upheaval in June, 1940.

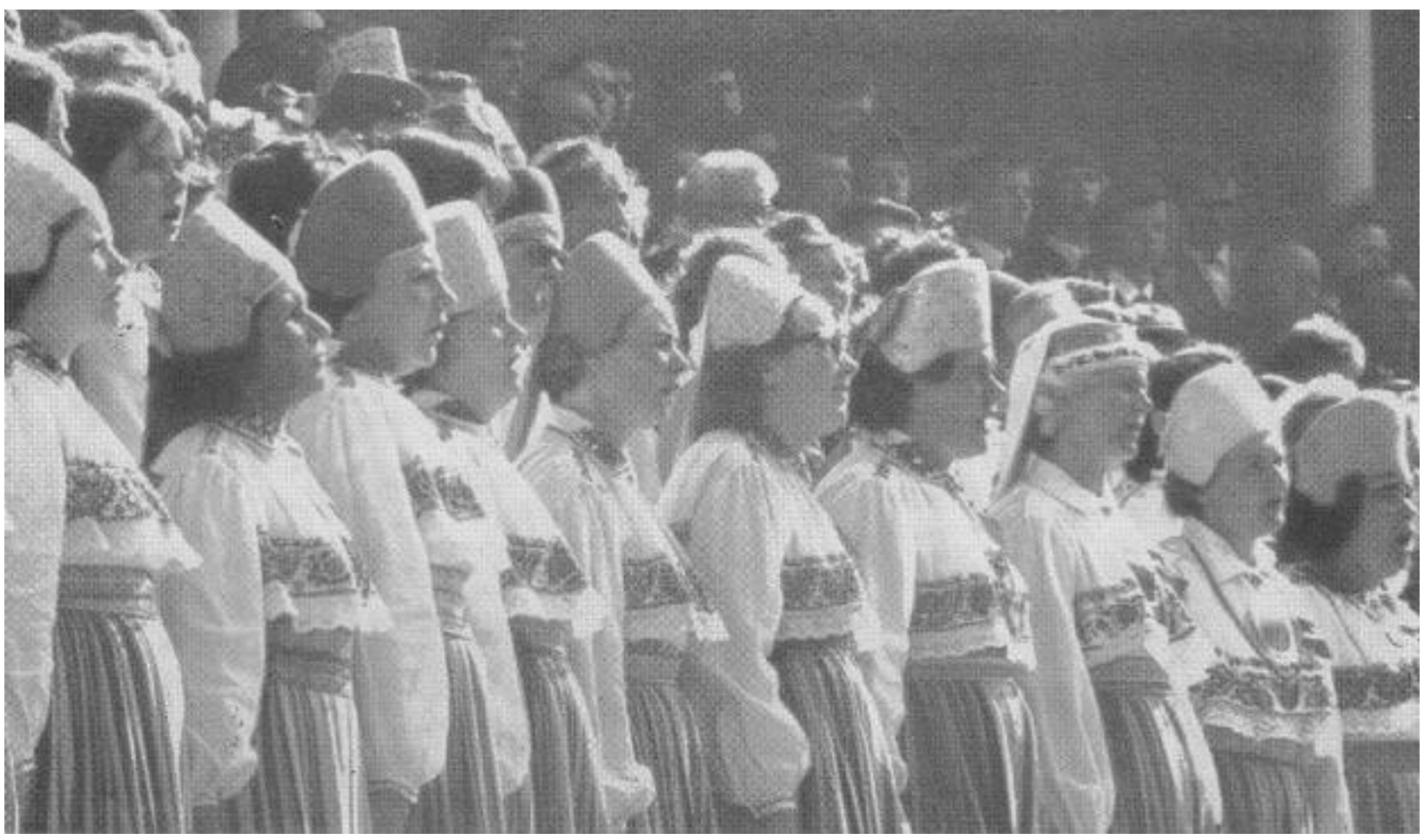

Fig 11. Women were working mainly in the chemical industry, leaving enough time to deal with hobbies liken singing choirs. This is a good example of showing "socialist content, nationalistic form" as they are wearing local regional national costumes (source: Sein 1976: 82).

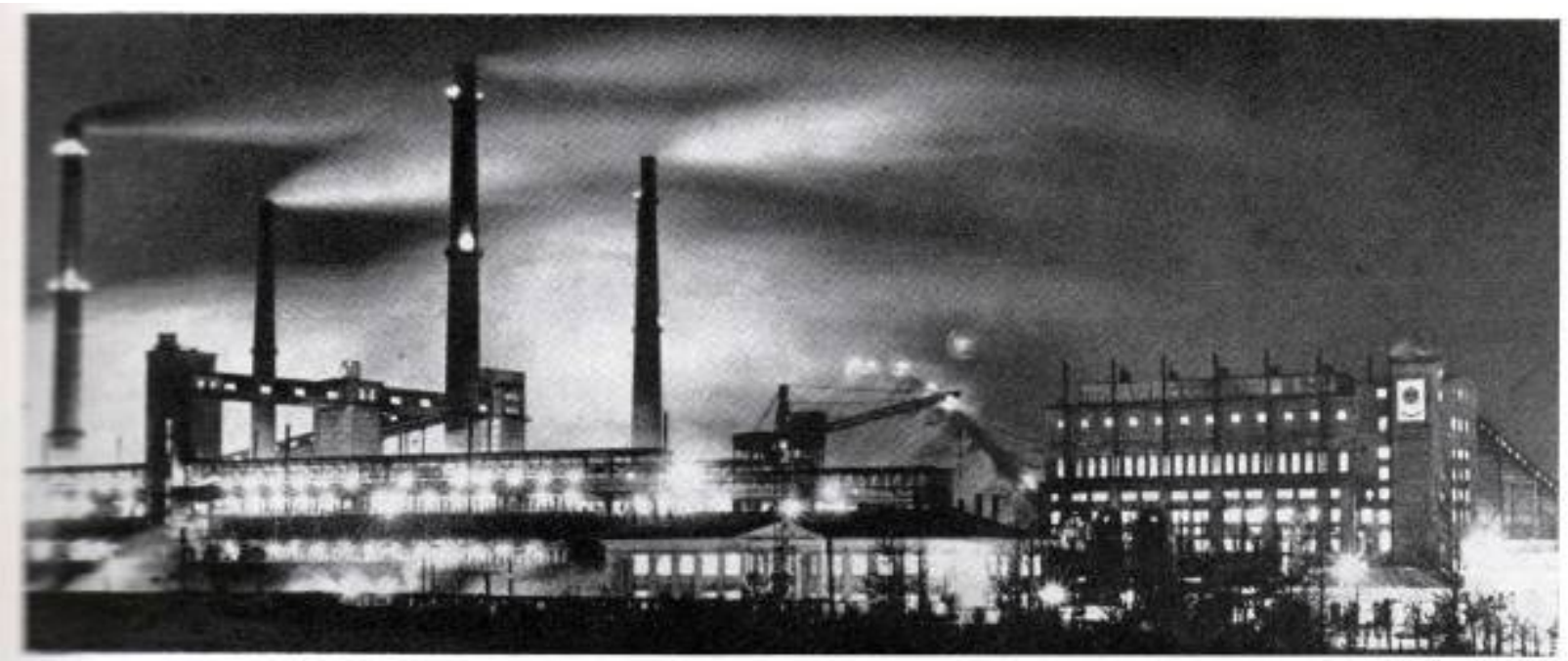

Fig 12. Kohtla-Järve's nightscape, glowing even in the dark to show the way (source: Sein 1976: 37).

Older story-tellers mention individual houses (an ideal type of home in Estonian imagery) on Punane street as something meaningful, for instance "everything was very beautiful, pretty, green on Punane street" (notice the colour ideological irony), "knew ones who had to leave their homes, their Punane street homes and taken out of their third home feet first". On the other hand the Soviet style city resembling all new cities across the Soviet Union was much more acceptable for immigrants than historic Estonian small cities (Jaago et al. 2007). Space had been domesticated to a proper place for immigrants; local Estonians felt that their place was eroding into anonymous space (figure 13). 
The "fruitful Soviet conditions" that accompanied oil-shale mining in city building had its consequences for everyday life as well. Up-to-date lodging opportunities and work places attracted young miners and educated scientists. No interior views of homes are represented in the books, quite contrary to the abundance of descriptions of them in life-stories: where and

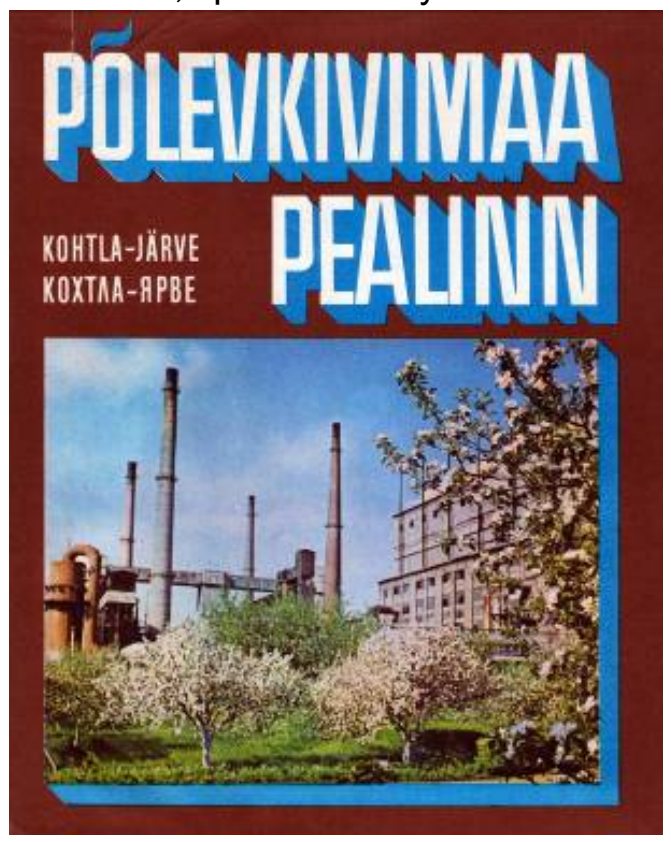

Fig 13. For those who can read the landscape (see Widgren 2004): blossoming apple trees are remnants of farmsteads that had to make way for industry (source: Sein 1976: cover). how things were retrieved in a constant state of deficit. In contrast, work and progress in industrialisation is not discussed in life-stories, concerning the Soviet as well as contemporary period. Perhaps diffusion of innovations is taken for granted or it is felt that public sphere of technology development belongs to the "big history", not worth mentioning unlike everyday living conditions. Retrospectively, all life-stories feature the theme of overall degradation (e.g. the building of the nitrogen fertiliser factory and expansion of the oilshale plants mentioned earlier), the feeling of sorrow as work once necessary was now deemed unimportant; feelings neglect and despair are evident, though environmental issues are not in the foreground as long as they do not affect day-to-day practicalities. Laundry days were selected according to the wind direction: no grime parts from the polluted air were wanted on freshly washed bed linen. Snow was prohibited for children to eat, not because of fear of catching cold but because of the contamination. Maybe here is the reason for the under-representation of winter-time photos in coffee-table books.

Monuments constitute a monumental importance in the city space for collective memory, creating identity and meeting places (Lynch 1970). Virtually every photo-album from the Soviet period starts with an image of the statue of Lenin, but none is ever mentioned in life-stories (figure 14). In books dealing with Kohtla-Järve more precisely another statue has deserved attention: "Glory to Work" (figure 15). It is fascinating that all the statues of Lenin have been removed and replaced by flower arrangements or just neglected and not depicted in photo-albums anymore, but two miners still stand in solitary pride on city hall square, although the tribune was made shorter in the 1990s. Kohtla-Järve's city government still used this statue in their official materials in 2008 as representatives of the working class (Kohtla-Järve's official web page).
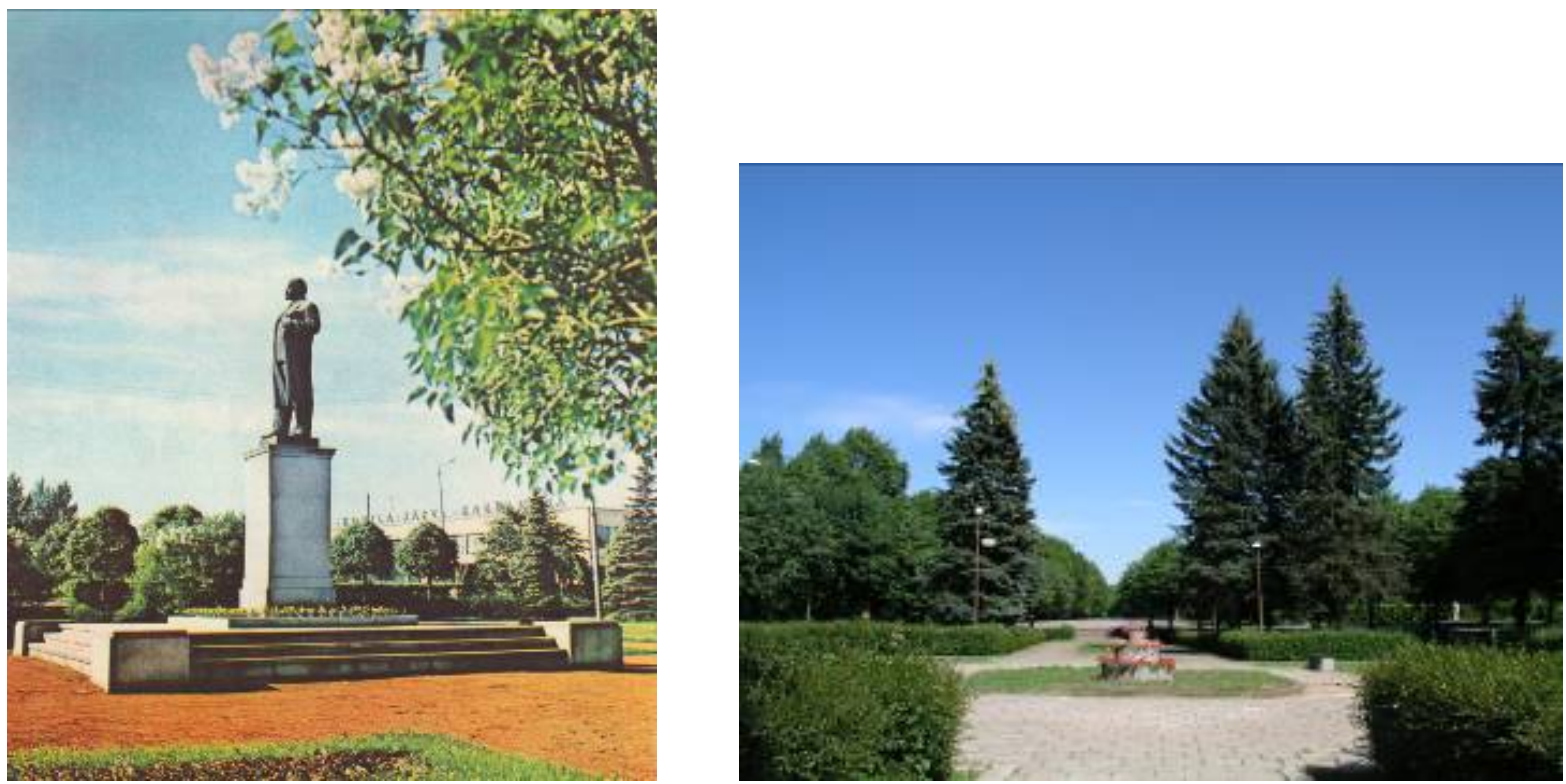

Fig 14. What has remained from Lenin's statue in so-called Old Town of Kohtla-Järve (source: Sein 1976: 6; photo: A. Printsmann, 2.07.2007). 


\subsection{Individuals}

The Soviet ideology strived to show that it was the working comrade, to whom all new benefits were created. The number of labourers' portraits supports the idea of valuing each and every person, where a simple miner is important enough to be represented as a class member in a photo-album. In "Miners' County" (Migdal 1968) 18 images out of 95 represent workmen (figure 16). In life-stories often the comparison with pawns occurs: people felt that they are insignificant in the big picture, submissive and unable to change the rules of the bigger game. Major changes are referred to in a passive voice (Jaago et al. 2007):

In the 1950s the settlement turned into [a place] densely populated by immigrants. Construction began. National culture was not that influential any more. Industries expanded and a Russian-speaking society emerged. There were no ethnic clashes. Russians were preferred, mostly for political reasons. Today there is almost no reluctance and the Russians are more [reluctant to the Estonian power].

Local city legend also mocks wives of Russian officers that were illiterate (many of the Soviets were sent to "bring culture") and in a wish to behave according to their high social status wore silk undergarments as evening gowns, found in abandoned houses right after the war.

Along with the modern Soviet city build-up, places for communal get-togethers were foreseen. The so-called house of culture was promoting spending spare time in an orderly manner, dealing with hobbies and recreation together with comrades. One can only assume that professionally fast-promoted Russian-speaking bosses did not dance Estonian folk dances with their employees.

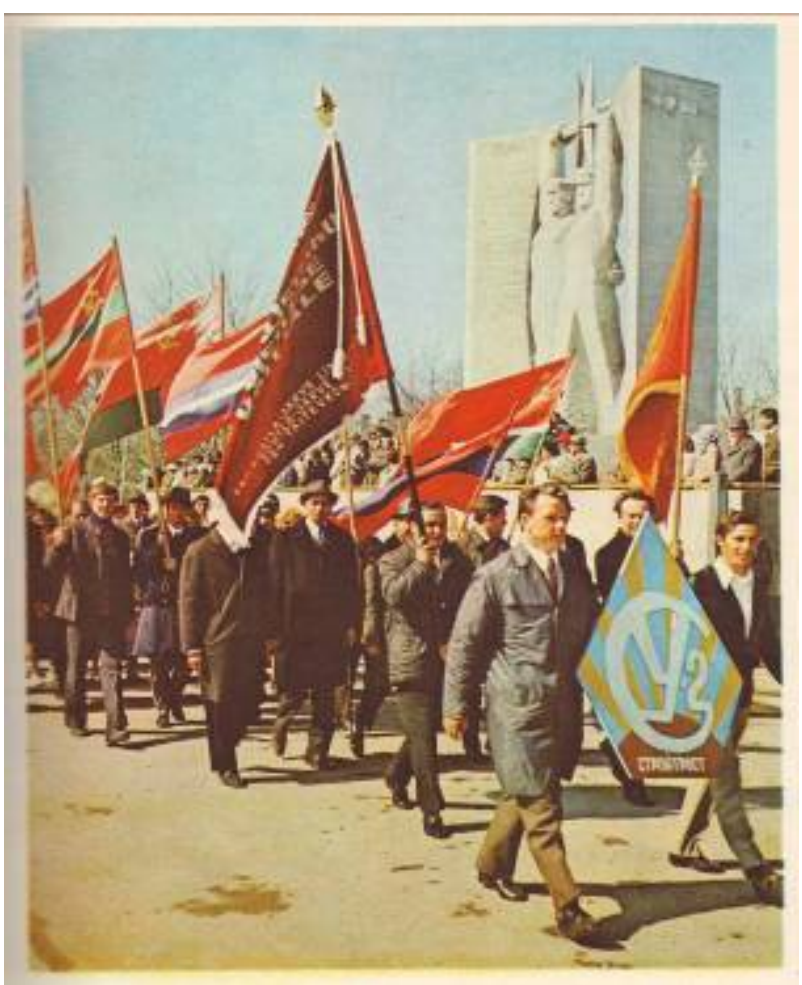

Fig 15. "In the morning of $1^{\text {st }}$ of May" by the "Glory to Work" monument and tribune, where the local party's apparatus greeted people when they marched by during parades. The flags seem especially red but it could be also just the print quality. The monument depicts two miners that the local lore calls as "the only two sober miners" referring to the problems of a hard working environment (source: Sein 1976: 5).workmanship (source: Sein 1976: 5).

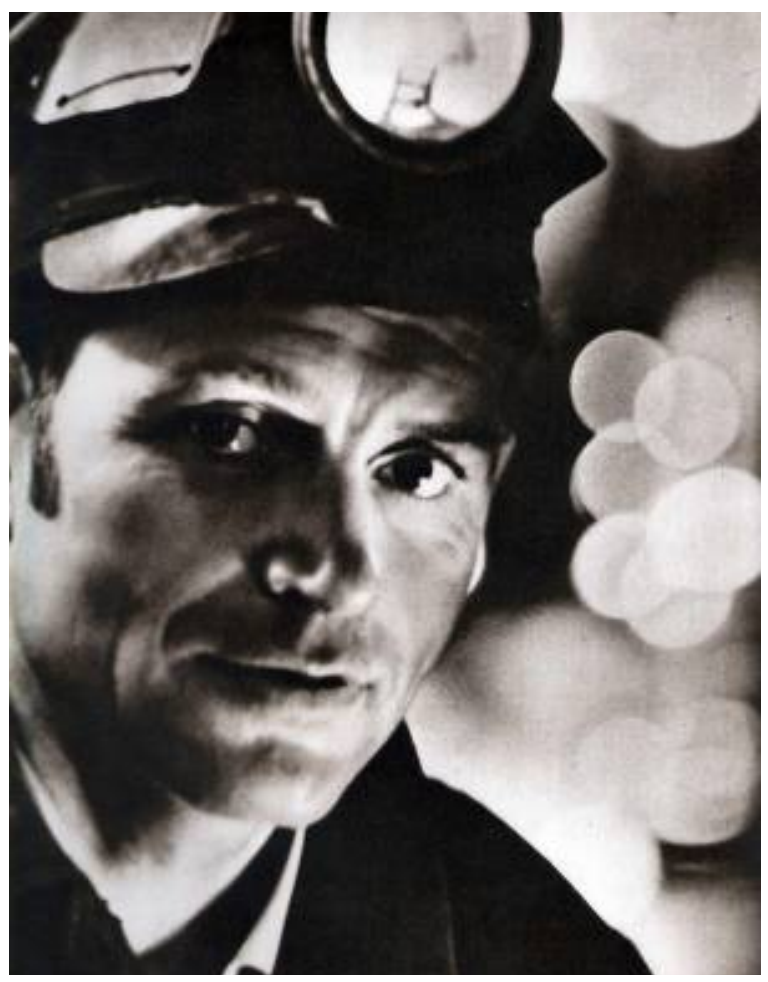

Fig 16. A miner (source: Migdal 1968: 16). 


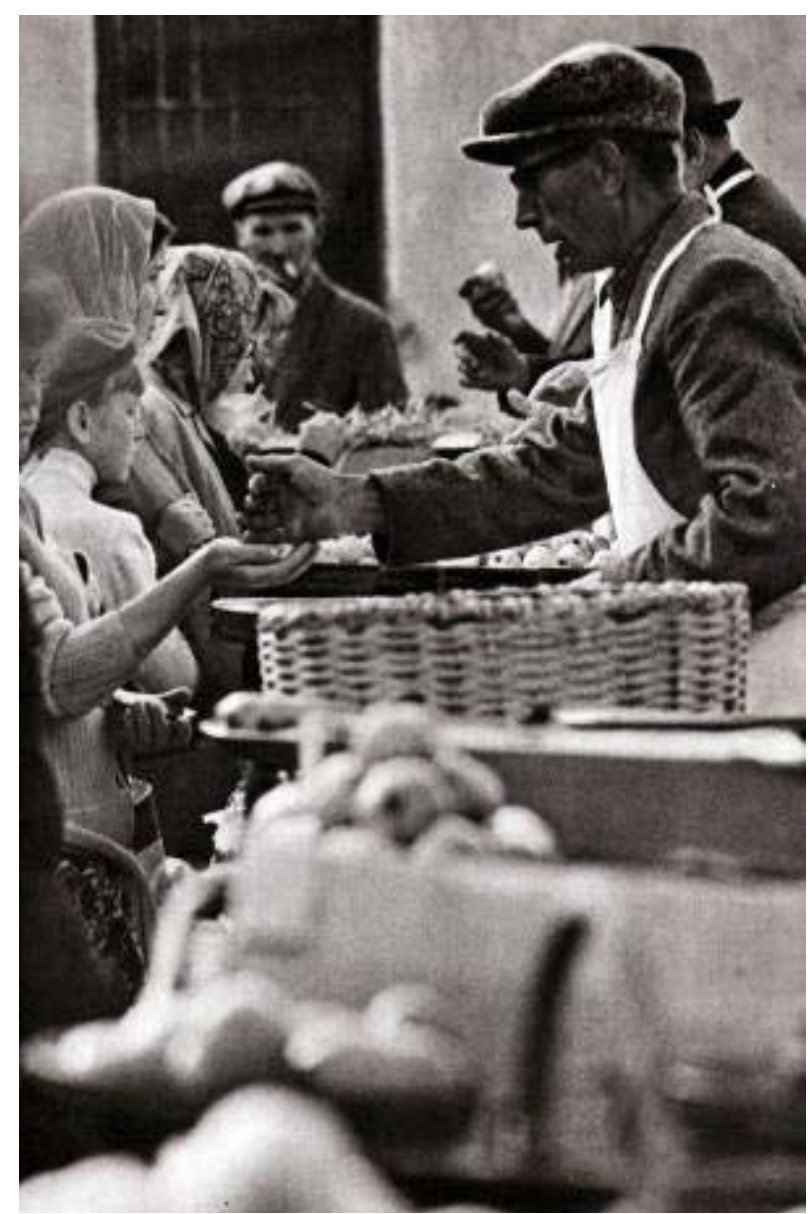

Fig 17. No ethnic tensions whatsoever in everyday market scene (source: Midgal 1968: 63).

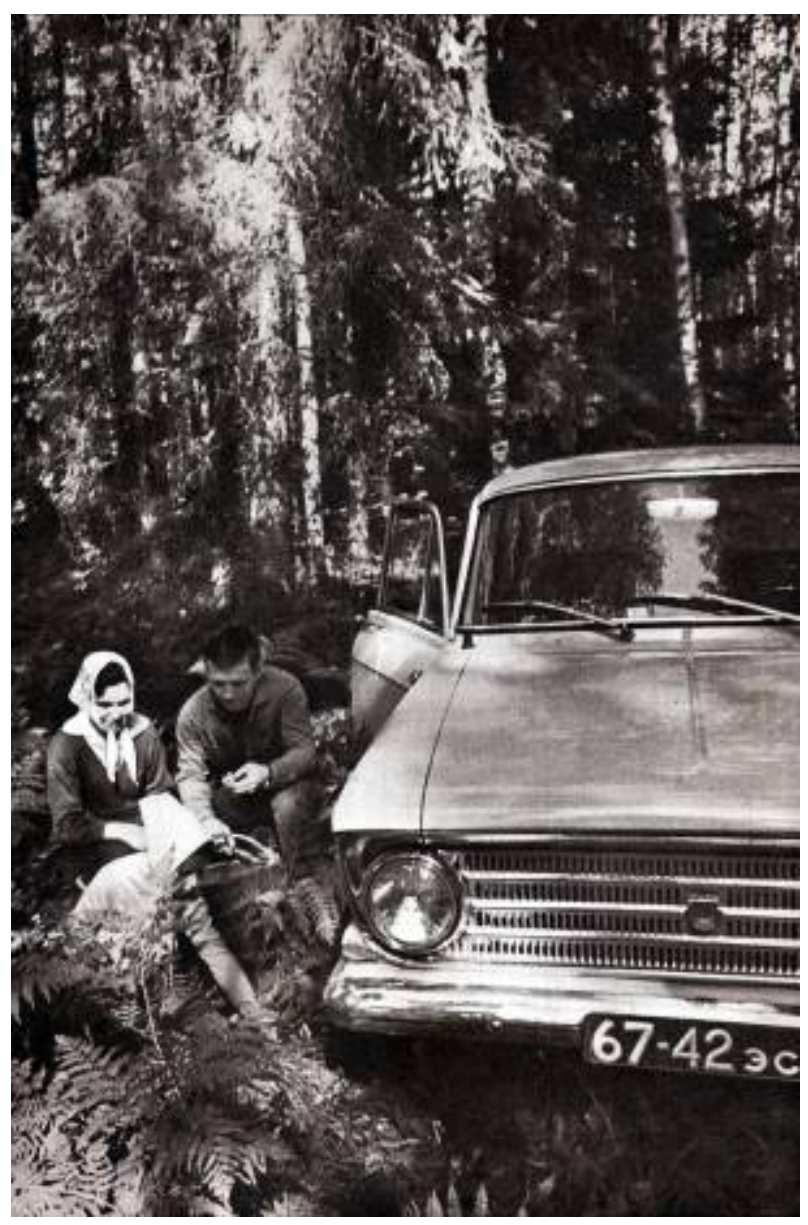

Fig 18. Not very realistic photo: own car, no organised activity, family is dealing with subsistence berrypicking (source: Migdal 1968: 83).

So-called folk hikes and tiding-up Saturdays were arranged rather regularly, often the most precious time for people having to take care of their subsistence gardens. Everyday's shadow economy, e.g. greenhouses, is never represented in photo-albums. Arranged cranberry and lingonberry picking trips for subsistence took place every year after September $15^{\text {th }}$ (planned economy) by busses (figure 17). Since the 1990s part of the Russian-speaking community faced difficulties in berry-picking as all the bilingual signs were substituted by place-names written in the Latin alphabet, thus they had to memorise the bus line numbers and at which kilometre they wanted the stop. Estonians perceive themselves as inward looking people, not so easily adaptable to the new; neither natural nor social environs (Jaago et al. 2007):

I just want to add that I have started liking this much-cursed Kohtla-Järve and receive gladly all messages about its past, life and people. /.../ For many years now I have participated in the "Third youth" club at the Kohtla-Nõmme clubhouse. There I have seen some exhibitions by local folklore researchers, and have even desired to contact them, but somehow I have remained passive; maybe I still feel alien. At least for the last 30 summers, all the forests and lands of Ida-Viru have been full of my footprints.

\section{Conclusions}

As the past is not a "coherent path to the present" (Agnew et al. 1997: 10) the shaping of the controversial Soviet mining city of Kohtla-Järve opens up through public and private spheres represented by imagery and life-stories during Estonia's recent Soviet past and the end of the Soviet system. Also, other contestations can be brought forward: of methods, times (e.g. application of methods in Estonian context and chronologies), space and place, insiders and outsiders.

Imagery and life-stories present a series of discrepancies especially during the Soviet but also contemporary period. The Soviet imagery stressed mining and industry, whereas contemporary 
imagery strives to erase it. Hopefully, this will start to change; people need to adapt to the environment where they spend their lives. In the totalitarian regime a picture in popular imagery may represent a thousand words that nobody cares to say. Neither time period's photos reflect reality as it comes out from life-stories. In the Estonian collective memory, until recently, the Soviet years were subjected to oblivion, as the Red Terror touched every Estonian family. Now, as time has passed, debates on how to recall the Soviet period have emerged and some sense of nostalgia is acceptable (see Vesilind 2006). Both representations and biographies are full of sensitive silences.

Yet, as contradictory as we would like to think the results of visual representational analysis and biographical approach concerning the Soviet and contemporary worlds are, they both still broadly follow the political situation and socio-economic circumstances. Imagery and life-stories are not poles apart, they just focus on different aspects; representations are rooted in real life and biographies are partly lived in public space.

One common turning point emerged in representations and life-stories: the 1970s when KohtlaJärve as oil-shale capital disappeared from photo-albums and local Estonian people felt the loss of an acceptable garden city due to modern high-rises and further industrialisation.

The same city space is shared by local Estonians; Estonians and Russian-speaking communities torn by ethnic conflict in some opinions. Their views of Kohtla-Järve differ because of their past personal histories that are reflected in their life-stories: what is noteworthy in landscape and worthwhile to mention. Surprisingly, very little attention is paid to the appearance of altered landscapes, e.g. ash-hills. For individuals, the ecological issues became a problem only when it directly concerned their everyday practicalities; and when general city maintenance was at a visible loss due to the number of immigrants who over-exceeded the local carrying capacity threshold. Furthermore, a similar aspect of common concern is the city's upkeep. An amazing ability to shifts one's focus from an outsider's to an insider's perspective is in evidence: Kohtla-Järve can be a "much-cursed" and "God-forsaken place" yet - still a home.

Imagery and life-stories alter in depicting changing landscapes in different circumstances, still featuring common themes and rules throughout the ages. Whether the mining and industrial history will be represented in photo-albums and life-stories in the future or not, it has constituted to the shaping of Kohtla-Järve.

\section{Acknowledgements}

I am deeply indebted to Helen Sooväli-Sepping for her invaluable input concerning visual representational analysis of landscapes and Tiiu Jaago who drew my attention to life-stories and how landscapes can be read out of those. I am grateful to my colleagues and the two anonymous reviewers for the comments to this paper.

This research was supported by the European Union through the European Regional Development Fund (Centre of Excellence in Cultural Theory), the Estonian Ministry of Education target-financed project no. SF0130033s07 "Landscape Practice and Heritage" and the Estonian Science Foundation grants no. 5858 "Transboundary Landscapes" and 6856 "Place-making in Urban Landscapes".

References

[1] Aarelaid-Tart, A. (2006). Cultural Trauma and Life Stories. Helsinki: Kikimora.

[2] Agnew, J., Livingstone, D.N. \& Rogers, A., Eds. (1996). Human Geography: An Essential Anthology. Oxford: Blackwell Publishers.

[3] Apo, S. (2003). Rahvapärase mõtteviisi uurimine arhiivi- ja küsitlusmaterjali abil. In Jaago, T. (Ed.), Pärimus ja tõlgendus. Artikleid folkloristika ja etnoloogia teooria, meetodite ning uurimispraktika alalt (pp. 218-233). Tartu: Tartu Ülikooli kirjastus,.

[4] Berg, E. (Ed.), (2002). Eesti tähendused, piirid ja kontekstid. Tartu: Tartu Ülikooli kirjastus. 
[5] Bryman, A. (2002). Series editor's foreword. In Roberts, B., Biographical Research. Series: Bryman, A. (Ed.), Understanding Social Research. Buckingham: Open University Press.

[6] Carson, R. (1968). Hääletu kevad. Tallinn: Valgus.

[7] de Certeau, M. (1988). The Practice of Everyday Life. Berkeley: University of California Press.

[8] Cosgrove, D.E. (1999). Introduction: mapping meaning (pp. 1-13). In: Cosgrove, D.E. (Ed.), Mappings. London: Reaktion Books.

[9] Cronon, W. (1999). A place for stories: nature, history, and narrative. In: Buttimer, A. \& Wallin, L. (Eds.), Nature, Culture, Identity in Cross-cultural Perspective (pp. 201-234). Dordrecht: Kluwer Academic Publishers.

[10] Duncan, J. (2000). Representation. In: Johnston, R.J., Gregory, D., Pratt, G. \& Watts, M. (Eds.), The Dictionary of Human Geography. $4^{\text {th }}$ edition (pp. 703-704). Oxford: Blackwell.

[11] Glaser, B.G. \& Strauss, A.L. (1967). The Discovery of Grounded Theory: Strategies for Qualitative Research. New York: Aldine De Gruyter.

[12] De Grave, V., Printsmann, A., Palang, H., van Eetvelde, V. \& Antrop, M. (2006). Schoolchildren's appreciation of the contested landscape of Ida-Viru county, Estonia. Alue ja Ympäristö 35(2), 55-68.

[13] Hall, S. (1997). Representation: Cultural Representations and Signifying Practices. London: Sage.

[14] Haraway, D. (1997). Situated knowledges: the science question in feminism and the privilege of partial perspective.

[15] Harvey, D. (1997). On the history and present condition of geography: an historical materialist manifesto. Reprinted in: Agnew, J., Livingstone, D.N. \& Rogers, A. (Eds.), Human Geography: An Essential Anthology (pp. 95-107). Oxford: Blackwell.

[16] Hinrikus, R., Ed. (2000). Eesti rahva elulood. Sajandi sada elulugu I-II. Tallinn: Tänapäev.

[17] Hinrikus, R., Ed. (2003). Eesti rahva elulood III. Elu Eesti NSV-s. Tallinn: Tänapäev.

[18] Hinrikus, R., Jõe-Cannon, I., Stiver Lie, S. \& Malik, L., Eds. (2006). Carrying Linda's Stones. An Anthology of Estonian Women's Life Stories. Tallinn: Tallinn University Press.

[19] Hinrikus, R. \& Kõresaar, E. (2004). A brief overview of life history collection and research in Estonia. In: Kirss, T., Kõresaar, E. \& Lauristin, M. (Eds.), She Who Remembers, Survives. Interpreting Estonian Women's Post-Soviet Life Stories (pp. 19-34). Tartu: Tartu University Press.

[20] Howard, P. (1991). Landscapes. The Artists' Vision. London: Routledge.

[21] Humphrey, R., Miller, R. \& Zdravomyslova, E., Eds. (2003). Biographical Research in Eastern Europe. Altered Lives and Broken Biographies. Aldershot: Ashgate.

[22] Itra, K., Ed. (1985). Eesti. Tallinn: Perioodika.

[23] Jaago, T., Printsmann, A. \& Palang, H. (2007). Kohtla-Järve: one place, different stories. In Näripea, E., Sarapik, V. \& Tomberg, J. (Eds.), Place and Location: Studies in Environmental Aesthetics and Semiotics VI (pp. 285-303). Tallinn and Tartu: Estonian Literary Museum, Estonian Academy of Arts.

[24] Jackson, J.B. (1984). Discovering the Vernacular Landscape. New Haven: Yale University Press.

[25] Jauhiainen, J. \& Kulu, H., Eds. (2000). Inimesed, ühiskonnad ja ruumid: inimgeograafia Eestis. Publicationes Instituti Geographici Universitatis Tartuensis 87. Tartu: Tartu Ülikooli kirjastus.

[26] Jüssi, F. (1973). Pilte Alutaguselt. Tallinn: Eesti Raamat. 
[27] Kirss, T., Kõresaar, E. \& Lauristin, M., Eds. (2004). She Who Remembers, Survives. Interpreting Estonian Women's Post-Soviet Life Stories. Tartu: Tartu University Press.

[28] Knapp, A.B. \& Ashmore, W. (1999). Archaeological landscapes: constructed, conceptualised, ideational. In: Ashmore, W. \& Knapp, A.B. (Eds.), Archaeologies of Landscape: Contemporary Perspectives. Social Archaeology (pp. 1-30). Oxford: Blackwell.

[29] Krim, A.J. (1973). Photographic imagery of the American city, 1840-1860. The Professional Geographer 25(2), 136-139.

[30] Kõresaar, E. (2004). Memory and History in Estonian Post-Soviet Life Stories. Private and Public, Individual and Collective from the Perspective of Biographical Syncretism. Dissertationes Ethnologiae Universitatis Tartuensis 1. Tartu: Tartu University Press.

[31] Lefebvre, H. [1974] (1991). Production of Space. Oxford: Blackwell.

[32] Lehari, K. (2006). Purification of landscapes. In Koht ja paik / Place and Location: Studies in Environmental Aesthetics and Semiotics V (pp. 109-118). Tallinn: Estonian Academy of Arts.

[33] Linnap, P. (2003). Pictorial Estonia. In Sarapik, V. and K. Tüür (eds.) Koht ja paik / Place and Location: Studies in Environmental Aesthetics and Semiotics III (pp. 433-444). Tallinn: Estonian Academy of Arts.

[34] Linnap, P. (2006). Fotoloogia. Dissertationes Semioticae Universitatis Tartuensis 10. Tartu: Tartu Ülikooli kirjastus.

[35] Lotman, J. [1984] (1990). Õigus biograafiale. Teksti ja autori isiksuse tüpoloogilisest suhestatusest. In Lotman, J. Kultuurisemiootika (pp. 365-385). Tallinn: Olion.

[36] Lynch, K. (1970). The Image of the City. Cambridge: Massachusetts Institute of Technology Press.

[37] Meinig, D.W., Ed. (1979). The Interpretation of Ordinary Landscapes: Geographical Essays. Oxford: Oxford University Press.

[38] Migdal, S. (1968). Kaevuritemaa. Край горняков. Tallinn: Eesti Raamat.

[39] Mitchell, W.J.T. (1994). Picture Theory. Chicago: University of Chicago Press.

[40] Olwig, K.R. (2004). "This is not a landscape": circulating reference and land shaping. In Palang, H., Sooväli, H. Antrop, M. \& Setten, G. (Eds.), European Rural Landscapes: Persistence and Change in a Globalising Environment (pp. 41-65). Dordrecht: Kluwer Academic Publishers.

[41] Paju, I. (2007). Tõrjutud mälestused. Tallinn: Eesti Entsüklopeediakirjastus.

[42] Palang, H., Printsmann, A., Konkoly Gyuró, É., Urbanc, M., Skowronek, E. \& Woloszyn, W. (2006). The forgotten rural landscapes of central and eastern Europe. Landscape Ecology 21(3), 347-357.

[43] Passerini, L., Ed. (1992). Memory and Totalitarianism. Oxford: Oxford University Press.

[44] Peil, T. (2006). Country report. Emerging, submerging and persisting ideas: is there social and cultural geography in Estonia? Social \& Cultural Geography 7(3), 463-491.

[45] Peil, T. \& Sooväli, H. (2005). Estonian national landscapes - the sum and its parts. In Peil, T. \& Jones, M. (Eds.), Landscape, Law and Justice (pp. 49-60). Oslo: Novus forlag.

[46] Peil, T., Sooväli, H., Palang, H., Oja, T. \& Mander, Ü. (2004). Estonian landscape study: contextual history. Be/Geo 2-3, 231-243.

[47] Ranniku,V. \& Uusi, H. (1993). Eesti põhjarannik. Северное побережие Эстоний. Estonian Northern Coast. Tallinn: Olion.

[48] Relph, Edward [1976] (1986). Place and Placelessness. Series: Scott, A.J. (Ed.), Research in Planning and Design. London: Pion. 
[49] Roberts, B. (2002). Biographical Research. Series: Bryman, A. (Ed.), Understanding Social Research. Buckingham: Open University Press.

[50] Rose, G. (2000). Vision and visuality. In Johnston, R.J., Gregory, D., Pratt, G. \& Watts, M. (Eds.), The Dictionary of Human Geography, $4^{\text {th }}$ edition (pp. 892-893). Oxford: Blackwell.

[51] Sack, R.D. (2001). The geographic problematic: moral issues. Norsk Geografisk Tidsskrift Norwegian Journal of Geography 55(3), 117-125. Doi: 10.1080/002919501753129862.

[52] Sarapik, V. (2002). Landscape: the problem of representation. In Laanemets, M., Sarapik, V. \& Tüür, K. (Eds.), Koht ja paik / Place and Location II (pp. 183-199). Tallinn: Estonian Academy of Arts.

[53] Strauss, A.L. [1987] (1994). Qualitative Analysis for Social Scientists. Cambridge: Cambridge University Press.

[54] Strauss, A.L. \& Corbin, J.M. (1990). Basics of Qualitative Research. Grounded Theory Procedures and Techniques. Newbury Park: Sage.

[55] Scott, H. (2004). Cultural turns. In Duncan, J.S., Johnson, N.C. \& Schein, R.H. (Eds.), A Companion to Cultural Geography (pp. 24-38). Malden: Blackwell.

[56] Sein, V. (1976). Põlevkivimaa pealinn Kohtla-Järve. Tallinn: Eesti Raamat.

[57] Sontag, S. (2002). On Photography. London: Penguin Modern Classics.

[58] Sooväli, H. (2004). Saaremaa Waltz. Landscape Imagery of Saaremaa Island in the $20^{\text {th }}$ Century. Dissertations Geographicae Universitatis Tartuensis 21. Tartu: Tartu University Press.

[59] Sooväli, H., Külvik, M. \& Palang, H. (2004). Rural landscape representations in Estonian imagery. In Punning, J.-M. (Ed.), Estonia. Geographical Studies (pp. 171-179). Tallinn: Estonian Academy Publishers.

[60] Sooväli, H., Palang, H., Kaur, E., Peil, T. \& Vermandere, I. (2003a). Combining approaches in landscape research: land use, landscape perception and representation in the transdisciplinary context on Saaremaa. In Palang, H. \& Fry, G. (Eds.), Landscape Interfaces: Cultural Heritage in Changing Landscapes (pp. 357-374). Dordrecht: Kluwer Academic Publishers,.

[61] Sooväli, H., Palang, H. \& Külvik, M. (2003b). The role of rural landscapes in shaping Estonian national identity. In European Landscapes: From Mountain to Sea (pp. 114-121). Tallinn: Huma.

[62] Thrift, N. (2000). Image. In Johnston, R.J., Gregory, D., Pratt, G. \& Watts, M. (Eds.), The Dictionary of Human Geography (pp. 371-372), $4^{\text {th }}$ edition. Oxford: Blackwell.

[63] Varb, N. \& Tambet, Ü., Eds. (2008). 90 aastat põlevkivi kaevandamist Eestis: tehnoloogia ja inimesed. Tallinn: GeoTrail KS.

[64] Vesilind, P. (1980). Return to Estonia. National Geographic Magazine 157(4), 485-511.

[65] Vesilind, P. (2006). Eesti aastal 1979. Tallinn: Varrak.

[66] Widgren, M. (2004). Can landscapes be read? In Palang, H., Sooväli, H., Antrop, M. \& Setten, G. (Eds.), European Rural Landscapes: Persistence and Change in a Globalizing Environment (pp. 455-465). Dordrecht: Kluwer Academic Publishers. 